\title{
Patterns in sexual reproduction of the dominant scleractinian corals at Rapa Nui (Easter Island): Pocillopora verrucosa and Porites lobata
}

\author{
Hagen Buck-Wiese ${ }^{1,2, *}$, Itziar Burgués ${ }^{1}$, Alba Medrano $^{1,3}$, \\ Teresa Navarrete-Fernandez ${ }^{1}$, Michel Garcia ${ }^{4}$, Evie A. Wieters ${ }^{1}$ \\ ${ }^{1}$ Estación Costera de Investigaciones Marinas and Center for Marine Conservation, Facultad de Ciencias Biológicas, \\ Pontificia Universidad Católica de Chile, Casilla 114-D, 832 Santiago, Chile \\ ${ }^{2}$ Department of Biology and Chemistry (FB2), Universität Bremen, 28359 Bremen, Germany \\ ${ }^{3}$ Departament de Biologia Evolutiva, Ecologia i Ciències Ambientals, Facultat de Biologia, Universitat de Barcelona, \\ Avda Diagonal 643, 08028 Barcelona, Spain \\ ${ }^{4}$ S.E.E.M ORCA Ltda, Caleta de Hanga Roa, 2770000 Rapa Nui, Chile
}

\begin{abstract}
Sexual reproduction is fundamental to the maintenance and recovery of coraldominated communities in high-latitude and isolated locations, where replenishment often depends on local reproductive activity rather than recruitment from distant reefs. Rapa Nui (Easter Island) is one of the most remote islands in the Pacific, lying at the southern, subtropical edge of the range of reef-building scleractinians. Here, we describe the sexual reproduction and timing of the 2 dominant corals, Pocillopora verrucosa and Porites lobata. Reproductive activity was inferred from the identification and staging of gametes via histological analyses of monthly samples collected from December 2012 to May 2014 at $12 \mathrm{~m}$ depth at Motu Tautara $\left(27^{\circ} 6.6^{\prime} \mathrm{S}\right.$, $109^{\circ} 25.5^{\prime} \mathrm{W}$ ) with in situ temperature records. In P. verrucosa, the observed hermaphroditic activity spanned from December to January, resulting in mature oocytes of $117 \mu \mathrm{m}$ mean diameter. In $P$. lobata, observed gonochoric activity spanned from December to March, resulting in mature oocytes of $180 \mu \mathrm{m}$ mean diameter. The observed initiation of gametogenic cycles coincided with the onset of spring warming in both species. Inferred spawning of $P$. verrucosa followed a relatively calm period of daily variance reduction in local in situ temperature and wind speed prior to the peak in thermal conditions, whereas inferred spawning of $P$. lobata coincided with peak temperatures in one year but not the other. We suggest temporal restrictions of disruptive coastal activities such as dredging during coral spawning periods and mitigation of land-based sources of pollution and watershed discharge that may reduce water quality.
\end{abstract}

KEY WORDS: Coral reproduction - Gametogenesis - Gonad histology - Spawning timing • Easter Island · Eastern Pacific

\section{INTRODUCTION}

Reproductive pattern, timing and degree of spawning synchrony within and among scleractinian coral species can vary widely among coral assemblages in different regions (e.g. Wilson \& Harrison 2003, Baird et al. 2009, Harrison 2011, Glynn et al. 2017, Romero-

*Corresponding author: h.buckwiese@gmail.com
Torres et al. 2017). Although early hypotheses suggested consistently reduced sexual reproductive activity, a restricted (seasonal) breeding season and greater spawning synchrony at high-latitude locations, recent analyses of contemporary geographically expanded datasets document generally weak latitudinal trends and context-dependency

( ) The authors 2018. Open Access under Creative Commons by Attribution Licence. Use, distribution and reproduction are unrestricted. Authors and original publication must be credited. 
(e.g. Wilson \& Harrison 2003, Guest et al. 2005a,b, Baird et al. 2009, Harrison 2011, Glynn et al. 2017). Indeed, a broad spectrum of reproductive patterns (e.g. from strongly seasonal to protracted spawning) have been documented at both tropical low-latitude and subtropical high-latitude locations (e.g. Wilson \& Harrison 2003, Guest et al. 2005b, Glynn et al. 2012, 2017). Even within a given region, diversity of reproductive schedules among populations/reefs appears common. For example, the relatively small, highly dispersed coral populations of the Eastern Pacific exhibit some disparate reproductive characteristics suggestive of local adaptation, as well as reproductive schedules that vary among locations and years, which seemingly reinforce reproductive isolation (Glynn \& Ault 2000, Glynn et al. 2017, Romero-Torres et al. 2017). Since many species appear to use a diverse array of proximate external cues such as temperature, calm periods and lunar phase to time maturation and spawning (Kojis \& Quinn 1981, Fadlallah 1983, Jokiel et al. 1985, Harrison \& Wallace 1990, van Woesik 2010, Harrison 2011), local differences in environmental regimes are often evoked to explain spatial variation in temporal reproductive patterns (e.g. van Woesik 2010, Romero-Torres et al. 2017).

Knowing the breeding phenology of corals at geographically remote locations is of particular interest (Kruger \& Schleyer 1998, Wilson \& Harrison 2003, Baird et al. 2009, 2015), not only because more isolated populations are expected to offer a greater chance of adapting to local environmental conditions, but also because limited sources of population replenishment are likely to make them more reliant on self-recruitment for recovery after disturbance. Thus, population persistence is likely more sensitive to the timing and frequency of local reproduction that indeed can determine dispersal, recruitment levels and connectivity (e.g. Carson et al. 2010, Kough \& Paris 2015, Romero-Torres et al. 2017). Moreover, reproductive phenology is sensitive to climate change (e.g. Sydeman \& Bograd 2009, Moore et al. 2011, Richards 2012, Poloczanska et al. 2013, Philippart et al. 2014), which is projected to be greater for high-latitude coral communities (Guinotte et al. 2003, Manzello et al. 2008, Doney et al. 2009, Kroeker et al. 2011). Thus, characterizing local sexual reproductive patterns in isolated, subtropical reef-building corals at the edge of geographic distributions provides an important benchmark for recognizing potential future shifts in climate change-sensitive phenology and assessing whether/when responsive shifts in reproductive phenology present a match or mistiming between cues used by adults to changes in the larval environment (e.g. Philippart et al. 2003).

The marine fauna of Rapa Nui (Easter Island; $27^{\circ} 7^{\prime} \mathrm{S}, 109^{\circ} 22^{\prime} \mathrm{W}$ ) is particularly isolated and distinct, with high endemism in some groups (e.g. mollusks: $42 \%$, fishes: $77 \%$; Friedlander et al. 2013). Scleractinian coral and zooxanthellae assemblages here, which are best developed along the northern and western coast and extend below $60 \mathrm{~m}$ depth, are at their austral limit (Hubbard \& Garcia 2003, Glynn et al. 2017). They share closest compositional affinities with the Eastern Tropical Pacific, rather than westward Polynesia (Glynn et al. 2007, 2017, Veron et al. 2015), and the documented lack of gene flow and restricted dispersal potential suggest that isolation from the central Pacific is persistent, even under variable El Niño-Southern Oscillation and La Niña conditions (e.g. Baums et al. 2012, Wood et al. 2014). Oceanographic barriers to gene flow and isolationby-distance likely further explain the enhanced genetic isolation of Rapa Nui populations, which indeed are genetically distant even from those across other regions of the Eastern Pacific (Forsman 2003, Paz-García et al. 2012, 2016, Lessios \& Baums 2017).

While ongoing molecular genetic studies suggest potential for re-classification of Pocillopora verrucosa as a separate endemic species (D. A. Paz-García \& E. A. Wieters unpubl. data), genetic distinction of Porites lobata at Rapa Nui appears to be on scale with intraspecies variation (Forsman et al. 2015). Given that these 2 species ( $P$. lobata and $P$. verrucosa), of the known 15 species for the island, are responsible for the vast majority (approx. 95\%) of total coral cover (Glynn et al. 2003, 2017, Wieters et al. 2014), and that both are highly genetically isolated, vulnerability and resilience of these vibrant communities are likely strongly reliant on self-recruitment of these populations. Indeed, recovery processes following a massive bleaching-induced disturbance event in 2000 (Wellington et al. 2001) were mostly driven by new recruitment (Wieters et al. 2014, Riegl et al. 2015). To date, nothing is known of the reproductive attributes and schedules of Rapa Nui scleractinians. As for many other subtropical, high-latitude coral communities, the Rapa Nui populations are exposed to a thermally variable environment with relatively strong seasonal changes (Glynn et al. 2003, Riegl et al. 2015, E. A. Wieters unpubl. data), which is likely to impose constraints on reproductive cycles. Likewise, frequent exposure to moderately strong to severe winds generates typically rough seas that, together with Antarctic swell, appear to at least partially impose limits on coral abundance at Rapa Nui (see Hubbard \& Garcia 
2003 for discussion), suggesting that calm periods could provide an important selective advantage that facilitates fertilization processes and/or local larval retention (e.g. van Woesik 2010).

Here, as a first step in beginning to understand the role of sexual reproduction in ecosystem function at Rapa Nui, we assessed whether and when dominant scleractinian corals are reproductively active; characterizing the sexual system, the mode of reproduction and gamete development, as well as breeding schedules and oocyte sizes of $P$. verrucosa and $P$. lobata. Geographic variation in reproductive mode and phenology have been documented in both species. In contrast to $P$. lobata, which may show no periodicity in reproduction at low latitude, single, annual gametogenic cycles have been documented for most of colonies of $P$. verrucosa even at locations in the Equatorial Eastern Pacific (Glynn et al. 1994, Campos-Vasquez 2014). Recognizing and taking into consideration the local patterns of reproductive phenology may help in the planning and mitigation of coastal activities at Rapa Nui.

\section{MATERIALS AND METHODS}

\section{Study site}

Coral samples were collected from mid-depths $(12-15 \mathrm{~m})$ at Motu Tautara $\left(27^{\circ} 6.6^{\prime} \mathrm{S}, 109^{\circ} 25.5^{\prime} \mathrm{W}\right.$ : Fig. 1) on the northwest coast of Rapa Nui, which is relatively more protected from severe waves generated by Antarctic ground swell originating from southern seas and, according to satellite imagery,

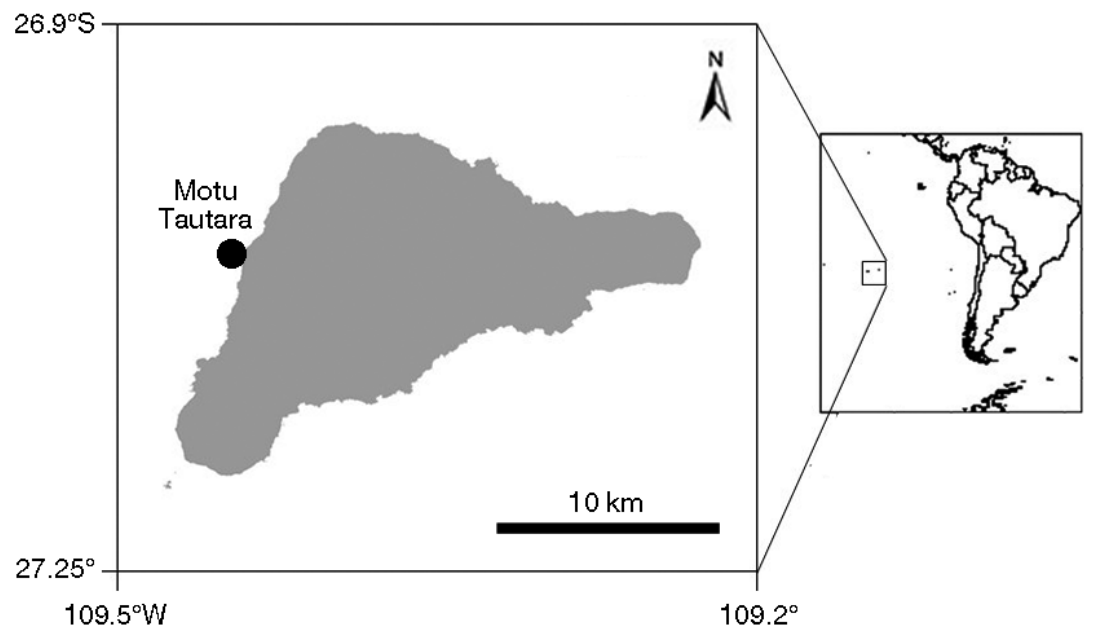

Fig. 1. Sampling site at Motu Tautara on the west coast of the island of Rapa Nui $\left(27^{\circ} 6.585^{\prime} \mathrm{S}, 109^{\circ} 25.446^{\prime} \mathrm{W}\right)$, which is located around $3000 \mathrm{~km}$ off the coast of continental Chile presents slightly higher $\left(0.1^{\circ} \mathrm{C}\right)$ mean sea surface temperature and lower $\left(0.002 \mathrm{mg} \mathrm{m}^{3}\right)$ chlorophyll a levels than the other 2 coasts (Andrade et al. 2014). Here, wind waves regularly create rough seas, and heavy surf is generated by the passing of weather fronts (Hubbard \& Garcia 2003). Winds blow throughout the year and are predominantly from east-southeast, but the influence of strong easterlies on the ocean surface can be felt even on the leeward northwest coast as energy is refracted and diffracted around the tips of the island. Unfortunately, local nearshore circulation patterns around the island are unknown, although surface circulation in the region is generally east to west (Glynn et al. 2007), and the island itself does modify the predominantly northwestern large-scale geostrophic flows (Moraga et al. 1999). Like most sites along the western and northern coasts where coral communities are particularly well developed, Tautara is characterized by overall high coral cover $(80 \%)$, with Pocillopora verrucosa and Porites lobata contributing similarly to total coral abundance (see Wieters et al. 2014 for quantitative description of temporal and geographic patterns in functional structure and coral abundances around the island).

\section{Environmental conditions}

To characterize the physical environment and shed light on potential proximate cues by which corals initiate gametogenesis and spawning, we examined in situ temperature and wind data. A temperature logger (TidBit@, Onset Computer) programmed to record instantaneous temperature every 10 min was deployed at $\sim 12 \mathrm{~m}$ depth at the study site. Wind data for the sampling period were obtained from the meteorological station of the Mataveri International Airport, located approximately $5 \mathrm{~km}$ from the study site, which recorded wind speed and direction at 20 min intervals. Because rough seas and surface disturbances along the northwest coast can result from moderate to high winds blowing from most any direction (see above), we analyzed directionless wind speed as a conservative estimate of calm periods that could potentially influence timing of gamete release. The daily mean, variance, maximum (as estimated by the 
$95 \%$ quantile) and rate of change were calculated for each monthly period in which corals were sampled. The relation between these abiotic conditions and reproductive activity were graphically explored. In addition, data on near-surface current velocity and direction were obtained from drifter observations (Laurindo et al. 2017). All statistics and graphics were computed/drawn using R v.3.3.1 (R Core Team 2016) and the package ggplot2 (Wickham 2010).

\section{Reproductive biology, condition and gamete development}

To describe reproductive biology, condition and gamete development, $P$. verrucosa and $P$. lobata were sampled monthly on the full moon between December 2012 and April 2014 at Motu Tautara. Coral fragments $(2-4 \mathrm{~cm})$ were randomly collected from 8-10 healthy, lesion-free colonies of similar size ( $P$. verrucosa: $20-30 \mathrm{~cm}$; $P$. lobata: $>50 \mathrm{~cm}$ diameter) distributed across 2 rocky reefs at mid-depth (12$15 \mathrm{~m})$. Fragments were immediately preserved in $95 \%$ alcohol.

Samples were decalcified in a $10 \%$ hydrochloric acid filtered seawater solution buffered with $1 \%$ EDTA. Longitudinal, circular and cross sections of each decalcified coral tissue were passed through an increasing ethanol concentration series, cleared in xylene and finally embedded in Paraplast@-paraffin media. Paraffin blocks were sectioned at $6 \mu \mathrm{m}$ thickness, and 3 different sections approximately $50 \mu \mathrm{m}$ apart were mounted on glass slides. Sections were stained using Harris' hematoxylin and phloxine and examined under $400 \times$ and $1000 \times$ augmentation using an Olympus CX21 microscope.

Each colony was categorized according to gamete presence, sex and presence of planula larvae. $P$. verrucosa samples were scored for presence/absence of gametes. Developmental Stages I-III and IV of oocytes were discriminated, in which Stage IV usually exhibited a diameter above $100 \mu \mathrm{m}$, enhanced accumulation of lipid droplets and a peripheral nucleus position (Stoddart \& Black 1985, Glynn et al. 1991, Kruger \& Schleyer 1998, Permata et al. 2000). For $P$. lobata, percentage composition of early (Stages I-III) and late (Stage IV) development status oocytes was inferred based on a diameter usually $>130 \mu \mathrm{m}$ and additional visual features. Stage IV oocytes were determined by displacement of the nucleus towards the periphery of the cell and becoming triangular or saddle-shaped as described by Glynn et al. (1994). The developmental stage of sper- maries could not be determined for either of the 2 species, since the ethanol fixation did not preserve tissue sufficiently to reliably assess division stages from spermatocysts to spermatozoa in most samples.

To further estimate temporal changes in oocyte size, oocytes were photographed using Microimage Camera 5.0 Megapixels model CO-05 and analyzed using Micrometrics SE Premium v.2.8 software. Diameters $(\mu \mathrm{m})$ in vertical $\left(D_{\mathrm{V}}\right)$ and horizontal $\left(D_{\mathrm{H}}\right)$ directions were determined for each of 30 randomly selected oocytes of each colony sampled. Average oocyte diameter $\left(D_{\mathrm{A}}\right)$ was estimated as $D_{\mathrm{A}}=\left(D_{\mathrm{V}}+\right.$ $\left.D_{\mathrm{H}}\right) / 2$.

\section{RESULTS}

\section{Environmental conditions}

A clear seasonal cycle was observed in seawater temperature at the study site (Fig. 2A,B). In general, austral winter to spring (June-November) temperatures were relatively low and presented overall little high-frequency (weekly, daily) variability. The onset of rapid warming during late spring, with marked peaks of high temperatures $\left(25.5-26.0^{\circ} \mathrm{C}\right)$ in summer, was accompanied by greater high-frequency (dayto-day) variability, with clear differences observed between years. Overall, the onset of spring warming was earlier and peak summer temperatures were higher and lasted longer in the summer of 2013 than of 2014. In contrast, wind speed appeared nonseasonal and overall similar across months throughout the year, with large high-frequency (daily, weekly) variability that presented a marked peak in early austral spring (September-November, Fig. 2C,D). Data from drifters revealed southeastbound surface currents to occur between January and March, whereas southwestward currents prevailed during the rest of the year (Fig. S1 in the Supplement at www.int-res.com/articles/suppl/b027 p001_supp.pdf).

Initiation of gametogenesis of Pocillopora verrucosa coincided most notably with the onset of rapid spring temperature rise. Spawning occurred after high-frequency, synoptic-scale variability in temperature and wind dropped so that conditions during the month were more stable and calm as compared to previous months (Fig. 2B, $\mathrm{D}_{i}$ also see Fig. S2). The onset of gametogenesis of Porites lobata in 2013/2014 similarly coincided with the rising spring temperature. $P$. lobata spawning occurred $\sim 2$ mo after $P$. verrucosa in both years, but coincidence with tempera- 

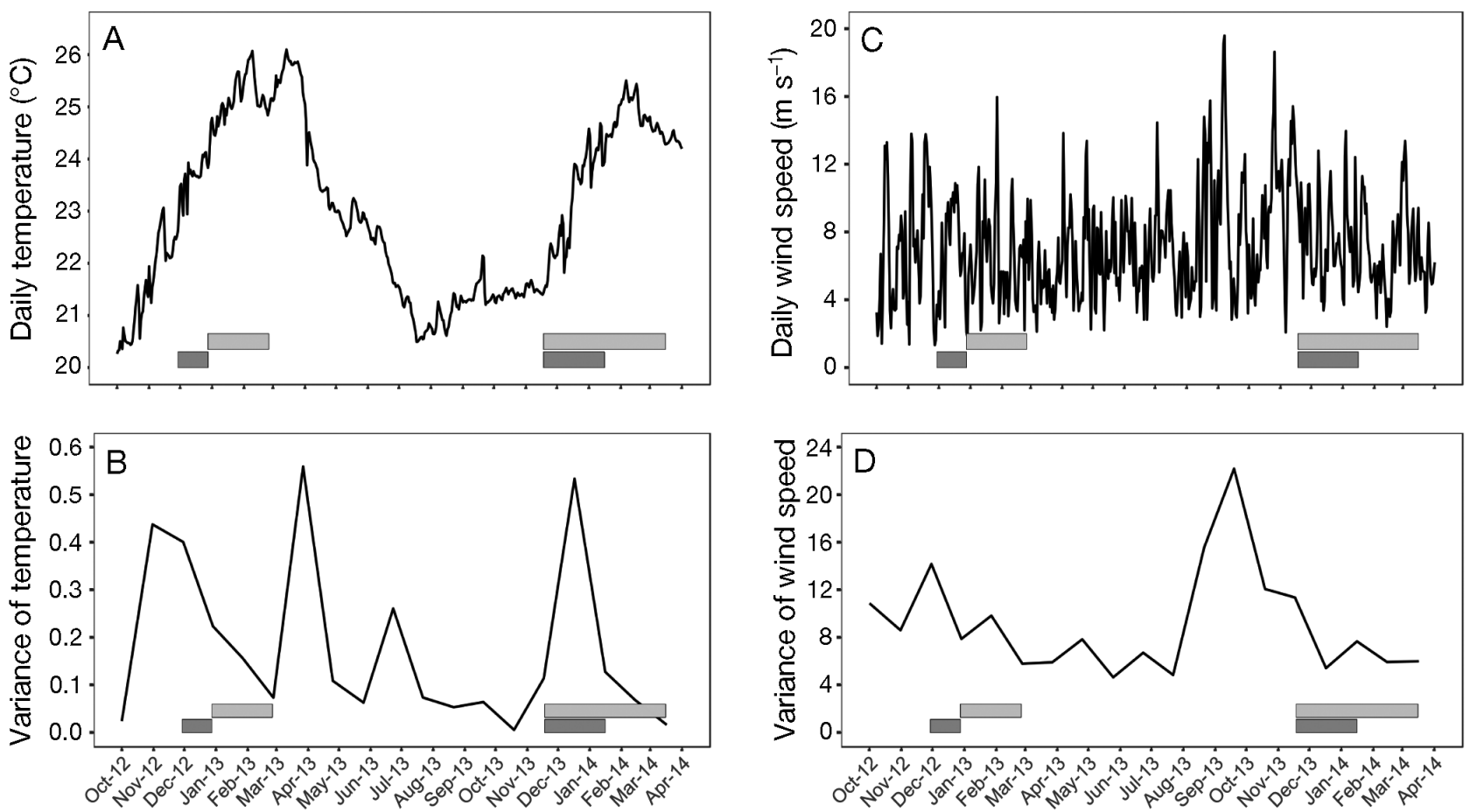

Fig. 2. Temperature and wind during the sampling period with reproductive periods of Pocillopora verrucosa (dark grey) and Porites lobata (light grey). $(\mathrm{A}, \mathrm{B})$ Temperature and $(\mathrm{C}, \mathrm{D})$ wind speed means per day and variance per month. Onset of oogenesis coincided with rising spring temperatures and ended before or around the summer peak for $P$. verrucosa and $P$. lobata, respectively. Predicted spawning times corresponded to periods of comparatively low and steady wind intensity

ture and wind conditions varied between years. In 2013, spawning month coincided with the peak in average temperature and when the variance in temperature and wind had sharply decreased, and similar, but weaker, coincidences were observed in 2014 when spawning occurred at least 1 mo after peak temperature was observed (Fig. 2A-D). Overall, for both species, timing of inferred spawning differed between years, occurring a month later in 2014 than in 2013.

\section{Characterization of gametes and reproductive modes}

Gametes were identified in colonies of both $P$. verrucosa and $P$. lobata, where either none or more than half of the examined polyps in each colony were observed to be reproductively active (presence of immature or mature gametes) at any one time. Planulae were never observed in histological sections, suggesting that both species broadcast spawn gametes.

For $P$. verrucosa, gametes of both sexes were observed within the same polyp (Fig. 3), and all reproductively active colonies presented both oocytes and spermaries. Oocytes were noted as round bodies, tightly packed in mesenteries with a dark purple stain. A bright pink nucleus was often visible in the center and yolk particles as non-stained dots in the periphery (Fig. 3A). Spermaries were identified as aggregations of small, intensively stained particles of roughly circular shape in cross-sections. In most cases, a central cavity could be observed in longitudinal sections opening towards the polyp surface and an outwards increasing density of colored particles (Fig. 3B). All gametes were located below the tentacles and surface level in a circular formation in crosssection perspective.

Colonies of $P$. lobata exhibited either female or male gametes (Fig. 4). Female colonies outnumbered males with an average sex ratio of 2.6:1 (Table S1 in the Supplement). Oocytes were irregularly shaped, consisting of a patchy bright cell body with a darker nucleus in a vaguely circular shape. In the periphery, they exhibited an intensively stained layer of aggregated zooxanthellae outside the oocytes (Fig. 4A,B). Spermaries appeared as darkly stained dots in dense masses with a conglomeration of bright pink filaments in the center (Fig. 4C). Both spermaries and oocytes were arranged in rows in mesenteries below 


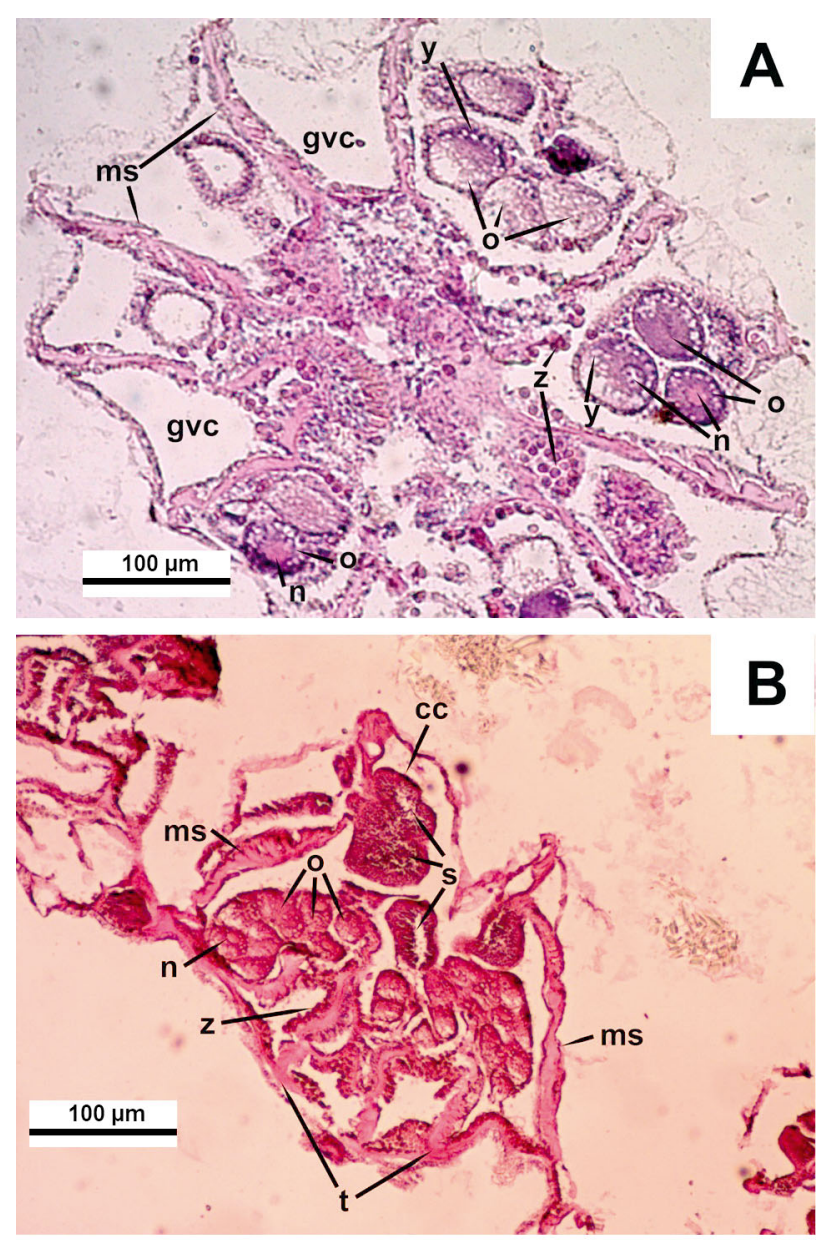

Fig. 3. Histological samples of Pocillopora verrucosa showing mesenteries containing oocytes and spermaries in the same polyp. (A) Cross-section of a polyp (sample from December 2012). (B) Longitudinal section of a polyp illustrating the position of gametes (sample from January 2014); gvc: gastrovascular cavity, ms: mesentery, o: oocytes, n: nucleus, y: yolk, cc: central cavities of spermaries, s: spermaries, z: zooxanthellae, t: tentacles

tissue surface in longitudinal sections (Fig. 4B,C), with decreasing gamete size towards the base, and exhibited a roughly circular arrangement in crosssections (Fig. 4A).

\section{Gametogenic schedules and oocyte size}

Gametogenesis of both coral species was strongly seasonal, with single, abrupt peaks in gonad incidence occurring in austral summer (December to March; Fig. 5). The rest of the year presented complete absence of any gametes. In general, peaks in reproductive activity of $P$. verrucosa preceded that of
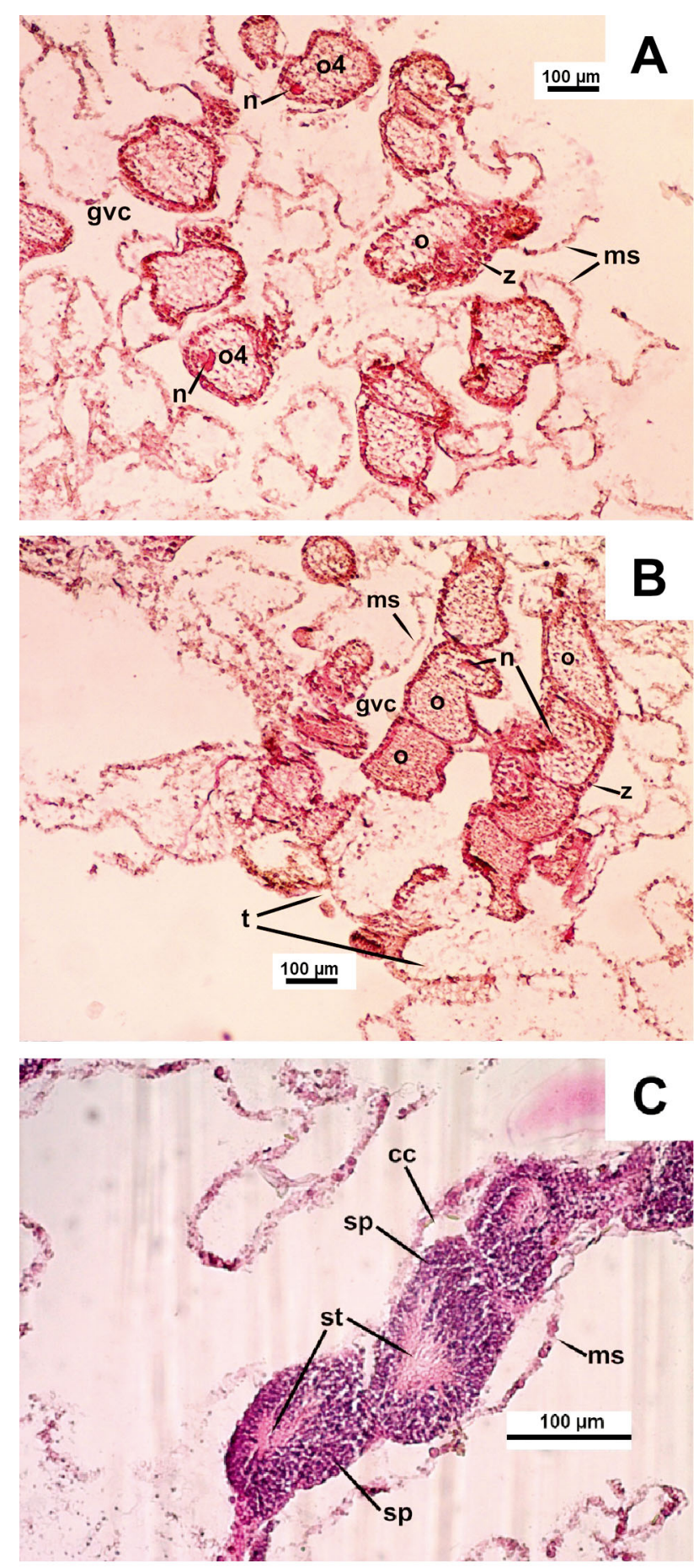

Fig. 4. Histological samples of Porites lobata colonies presenting either only oocytes or only spermaries. (A) Positions of oocytes in a longitudinal section. (B) Corresponding longitudinal section (both from January 2014). (C) Crosssection of a polyp with spermaries (sample from February 2014); gvc: gastrovascular cavity, ms: mesentery, o: oocyte, o4: Stage IV oocyte, n: nucleus, z: zooxanthellae, cc: central cavities of spermaries, sp: spermatozoa, st: spermatozoa tails, t: tentacles 

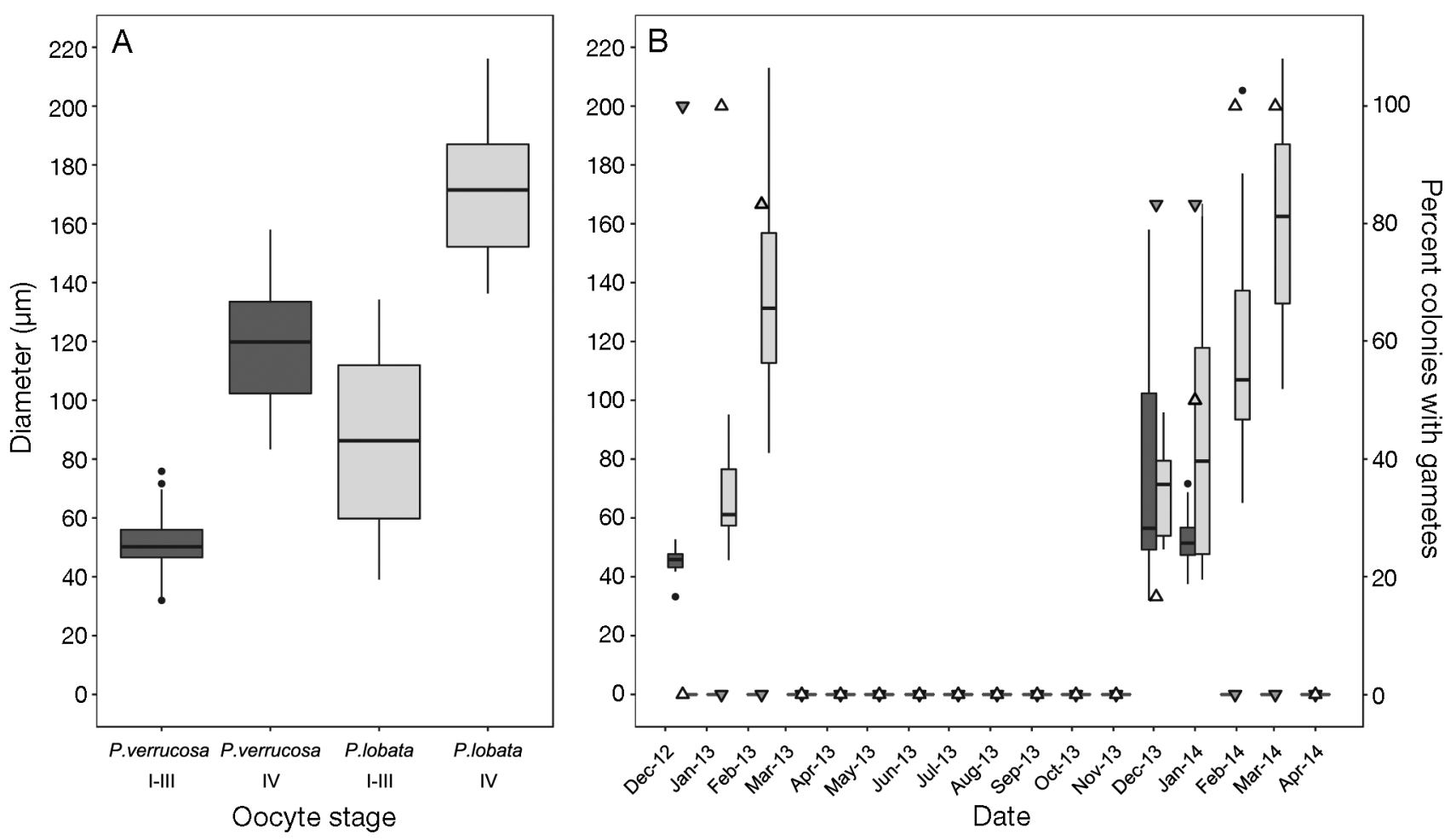

Fig. 5. Oocyte sizes and percentage of reproductively active colonies of Pocillopora verrucosa (dark grey) and Porites lobata (light grey). (A) Immature (Stage I-III) and mature (Stage IV) oocyte sizes. (B) Observed oocyte sizes for each sampling date, with percentage of colonies containing gametes in triangles (pointing downwards: $P$. verrucosa, upwards: $P$. lobata). In the boxplots, the horizontal line corresponds to the median and the lower and upper hinges to the first and third quartile, respectively. The whiskers extend to the lowest and highest value within 1.5 times the inter-quartile range. More distant values are individually represented as dots

P. lobata by 2 mo each year, and the reproductive season for both species was off-set by at least 1 mo between one year to the next, occurring later in 2014. While developmentally advanced oocytes were present throughout the breeding season in P. verrucosa, $P$. lobata colonies exhibited a marked trend of maturation towards the end of a season.

The length of the breeding season was more abbreviated for $P$. verrucosa than $P$. lobata. $P$. verrucosa presented recognizable gametes in December 2012 and from December 2013 to January 2014. Since the time series only began in December 2012, we were unable to confidently estimate the initiation and duration of gametogenesis this year. P. lobata gametes were identified during 2 successive months in summer 2012-2013 and 4 mo in summer 2013-2014, when a more gradual increase in the proportion of reproductively active colonies was observed (Fig. 5B).

$P$. verrucosa presented generally small average ova that decreased in consecutive months in 2013-2014, which was largely explained by greater amongcolony variability in December 2013 when 2 colonies presented much larger (mean $\pm \mathrm{SD}, 107.8 \pm 27.6 \mu \mathrm{m}$,
Stage IV) oocytes. The majority of clearly distinguishable oocytes was in Stage III $(50.2 \pm 7.1 \mu \mathrm{m})$, with abundant lipid droplets in the ova periphery (Fig. 3). Overall, P. lobata presented generally larger mature oocytes than $P$. verrucosa (Fig. 5A), with maximum observed diameters of 260.6 and $158.0 \mu \mathrm{m}$, respectively. Temporal progression in the proportional increase of mature (Stage IV) oocytes concurrently with mean ova size within a breeding season was clearly observed in $P$. lobata, but not $P$. verrucosa (Fig. 5B). Stage IV oocytes of P. lobata (180.4 \pm $30.5 \mu \mathrm{m}$ ) were dominant during the final month of the reproductive season when immature stages $(86.9 \pm$ $28.4 \mathrm{\mu m}$ ) were almost absent. For P. lobata, size progression was more gradual, and larger oocytes were attained in 2014 than 2013 (Fig. 5B).

The general timing (month) of gamete release was inferred by the abrupt (from one month to another) absence of gametes subsequent to the documented presence of mature gametes. Spawning in situ was not observed due to logistical difficulties limiting sampling effort. Because predominantly mature oocytes were observed in the month prior to gamete 
absence in P. lobata, spawning month appeared synchronous among colonies and occurred in later February or March in 2013 and 2014, respectively. P. verrucosa, on the other hand, completed the release of gametes about 2 mo earlier, likely in late December to early January in 2013 and late January to early February in 2014 (Fig. 5B).

\section{DISCUSSION}

Despite marginal location and extreme geographic isolation, dominant corals at Rapa Nui are sexually reproductive and, similar to most conspecifics elsewhere, are broadcast spawners. Pocillopora verrucosa was identified as a simultaneous hermaphrodite, whereas Porites lobata was gonochoric with sex ratios dominated by females. Reproduction was strongly seasonal, with a reproductive peak activity in early ( $P$. verrucosa) or mid- to late $(P$. lobata) austral summer. Gametogenic cycles were overall between 2 and $4 \mathrm{mo}$, with $P$. verrucosa showing a more abbreviated breeding season. The observed initiation of gametogenic cycles coincides with the onset of spring warming in both species. Inferred spawning of $P$. verrucosa followed a calmer period of daily variance reduction in temperature and wind speed prior to the peak in thermal conditions, whereas inferred spawning of $P$. lobata coincided with peak temperatures in one year but not the other.

While sexuality among scleractinians is highly conserved, the mode of larval development is relatively malleable in corals (Baird et al. 2009, Kerr et al. 2011). The observed patterns for each species at Rapa Nui are generally similar to those described for other locations in the Pacific. The mixed distribution of male and female gametes in single polyps confirms that $P$. verrucosa at Rapa Nui are simultaneous hermaphrodites, as is common for Pocilloporidae (Babcock et al. 1986, Baird et al. 2009). This reproductive mode is particularly favorable in small populations, as it ensures the presence of gametes of both sexes (Richmond 1997). Oocyte size features are very similar to other populations of $P$. verrucosa previously examined in diverse regions (Kojis \& Quinn 1981, Harriott 1983, Babcock et al. 1986, Richmond \& Hunter 1990, Glynn et al. 1991). The absence of fully matured oocytes in most colonies (cessation at Stage III) is similar to elsewhere and may be explained by rapid maturation in the last days or weeks before spawning. Such rapid maturation occurred at new moon for $P$. verrucosa in South Africa (Kruger \& Schleyer 1998), whereas samples in our study were collected at full moon, which could explain why Stage IV oocytes were largely absent. However, Great Barrier Reef P. verrucosa, and also $P$. lobata, are reported to spawn several days after full moon (Babcock et al. 1986, Schmidt-Roach et al. 2012). Our sampling frequency does not provide sufficient information to determine the timing of spawning in the lunar cycle of Rapa Nui corals.

In contrast, $P$. lobata colonies exhibited either oocytes or spermaries, suggesting a gonochoric population as reported previously from numerous other locations (Richmond \& Hunter 1990, Neves 2000, Baird et al. 2009). Sex ratio in the analyzed samples was skewed towards female colonies. Dominance of a particular sex likely varies across space, e.g. due to asexual reproduction via fragmentation, and depends on disturbance history (Glynn et al. 2017), but whether sex ratios in this work represent natural distribution or an artifact of small sample size should be assessed by more extensive sampling for a reliable conclusion. Since no planulae were observed in our histological analyses, we confirmed that both species at Rapa Nui are broadcast spawners.

In high-latitude locations, $P$. verrucosa populations possess relatively short breeding seasons of about $4 \mathrm{mo}$, which are restricted to spring and summer (Red Sea: Fadlallah 1983; Maldives Islands: Sier \& Olive 1994; South Africa: Kruger \& Schleyer 1998). The duration of gametogenic cycles at Rapa Nui is far shorter, with reproductive activity restricted to about 2 mo. Faster development of gametes may be attributed to strongly seasonal environmental conditions experienced at Rapa Nui, where winter temperatures are frequently below $18^{\circ} \mathrm{C}$ and the duration of seasonal, rapidly rising temperatures is restricted to 2-4 mo. Records of $P$. verrucosa gametogenesis length range from 2-3 up to 6 mo (Fadlallah 1983, Shlesinger \& Loya 1985, Kruger \& Schleyer 1998, Campos-Vasquez 2014). Thermal constraints have been invoked to explain short oogenic cycles at other high-latitude locations with similar thermal conditions (e.g. Lord Howe Island; Permata et al. 2000, Baird et al. 2015, Riegl et al. 2015).

Seasonal reproductive patterns for $P$. lobata match other populations with strong trends towards the summer months (Kojis \& Quinn 1981, Harriott 1983, Babcock et al. 1986, Richmond \& Hunter 1990, Glynn et al. 1994) and a reproductive season of 3 to 4 mo with a rapid development in the last 2 wk before spawning (Stoddart et al. 2012). Late-stage oocytes were similar in size in both years and matched observations of oocyte sizes in other populations in as well (Glynn et al. 1994, Stoddart et al. 2012). In contrast to other eastern Pacific populations, no zooxanthellae 
were observed inside oocytes at Rapa Nui. Since zooxanthellae transfer to oocytes is reported to occur weeks, days or even hours before spawning, the lack of evidence for vertical transmission may be an artifact of our monthly sampling and thus requires more frequent efforts to resolve with confidence.

The considerable differences in oocyte size among colonies of $P$. verrucosa sampled on the same day, particularly in December 2013, suggests rapid maturation and potential for several spawning dates and a lower degree of synchrony for this species. However, whether such a pattern reflects individual colony behavior or that of different colonies spawning at different times requires further study that includes monitoring of tagged colonies. Spawning of hermaphroditic species may be under less pressure for synchrony, as ova and sperm are provided simultaneously. P. lobata, in contrast, presented gradually increasing reproductive activity throughout the breeding season, with clearer and more synchronous (among-colony) progression towards maturity. However, high-frequency sampling would be required to truly assess among-colony spawning synchrony.

Sampling likely began too late in 2012 to confidently capture the earliest data of gamete presence, and thus we restrict our estimate to the following year's breeding season. Initiation of gametogenesis coincided with water temperature rise in spring 2013 for both species. The end of breeding seasons, when all colonies appeared to have spawned, consistently occurred after 1 mo of reduced daily variance in temperature and wind speed, prior to the peak in thermal conditions. Both may be of importance for successful fertilization and settlement, as spawned gametes may be dispersed and drifted away from suitable terrain when conditions are unsteady (van Woesik 2010, Baird et al. 2015). In addition, high environmental variability may simultaneously lessen the survival rates of sensitive planktonic larvae (e.g. Doropoulos et al. 2015).

The time shift in reproductive timing from one year to another might be causally linked to the delay of temperature rise in spring, as the temperature started to increase around the end of November during the first season and around mid-December in the second season. Temperature has previously been identified as a controlling mechanism for gametogenesis (Babcock et al. 1986, Glynn et al. 1991), and later onset of spring temperature rise may retard spawning (Wilson \& Harrison 2003). Such year-toyear changes in reproductive timing may be crucial to larval development and/or local recruitment success and could reflect either augmented risk if differ- entially matched with favorable oceanographic conditions that determine propagule supply and local connectivity or, alternatively, indicate that corals are well-adapted to changing conditions such that they are consistently matched to suitable environmental conditions. Which one of these applies depends on the mechanism driving phenology, but patterns here suggest that $P$. verrucosa presented more consistent matching with similar temperature conditions between years. This topic is open for future studies.

The strongly seasonal and particularly abbreviated duration of sexual reproduction of corals at Rapa Nui facilitates its consideration in local management plans of coastal activities (e.g. dredging, release of waste, etc.), which could be temporally restricted to enhance coral reproductive success. This seems particularly critical for Rapa Nui, given that populations of both ecologically dominant species are known to be strongly genetically isolated (e.g. Forsman 2003, Paz-García et al. 2012) and thus no external input of larvae can compensate for local reproductive failures. Dominant currents in a southeastern direction during spawning periods might lead to high degrees of pelagic larval retention along the western and northern coasts and possibly explain the absence of coral communities on the southeastern coast. Selective processes, which have been reported from other locations, may, therefore, be particularly critical at Rapa Nui, including the apparent greater importance of days to weeks of consistent environmental conditions. Thus, we hope the information presented here can contribute to building ecological literacy for decisions supported by the native Rapa Nui population along with governmental and non-governmental agencies, which are currently debating about community-driven conservation and management plans for the island. Our results offer an important benchmark for understanding and recognizing future changes in phenology and begin to place them in light of existing year-to-year variability.

Acknowledgements. Funding was provided by FONDECYT project no. 113016 to E.A.W. and the Center for Marine Conservation Grant ICM-CCM RC130004 of Iniciativa Cientifica Milenio of the Ministerio de Economia, Fomento y Turismo. We thank Dorothy Ellen Abigail Renegar and Veronica Flores for their guidance and logistical assistance with histological analyses.

\section{LITERATURE CITED}

Andrade I, Hormazábal S, Correa-Ramírez M (2014) Timespace variability of satellite chlorophyll-a in the Easter Island Province, southeastern Pacific Ocean. Lat Am J Aquat Res 42:871-887 
Babcock RC, Bull GD, Harrison PL, Heyward AJ, Oliver JK, Wallace CC, Willis BL (1986) Synchronous spawnings of 105 scleractinian coral species on the Great Barrier Reef. Mar Biol 90:379-394

Baird AH, Guest JR, Willis BL (2009) Systematic and biogeographical patterns in the reproductive biology of scleractinian corals. Annu Rev Ecol Evol Syst 40:551-571

Baird AH, Cumbo VR, Gudge S, Keith SA, Maynard JA, Tan C, Woolsey ES (2015) Coral reproduction on the world's southernmost reef at Lord Howe Island, Australia. Aquat Biol 23:275-284

Baums IB, Boulay JN, Polato NR, Hellberg ME (2012) No gene flow across the Eastern Pacific Barrier in the reefbuilding coral Porites lobata. Mol Ecol 21:5418-5433

Campos-Vasquez RA (2014) Ciclo reproductivo de los corales Pocillopora verrucosa (Ellis y Solander, 1786) y Pocillopora meandrina (Dana, 1846) en Isla Gaviota, Bahía de La Paz, México. MSc thesis, Instituto Politécnico Nacional, Mexico City

Carson HS, López-Duarte PC, Rasmussen L, Wang D, Levin LA (2010) Reproductive timing alters population connectivity in marine metapopulations. Curr Biol 20:1926-1931

Doney SC, Fabry VJ, Feely RA, Kleypas JA (2009) Ocean acidification: the other $\mathrm{CO}_{2}$ problem. Annu Rev Mar Sci 1:169-192

Doropoulos C, Ward S, Roff G, González-Rivero M, Mumby PJ (2015) Linking demographic processes of juvenile corals to benthic recovery trajectories in two common reef habitats. PLOS ONE 10:e0128535,

Fadlallah YH (1983) Sexual reproduction, development and larval biology in scleractinian corals: a review. Coral Reefs 2:129-150

Forsman Z (2003) Phylogeny and phylogeography of Porites \& Siderastrea (Scleractinia: Cnidaria) species in the Caribbean and Eastern Pacific; based on the nuclear ribosomal ITS region. $\mathrm{PhD}$ dissertation, University of Houston, TX

Forsman Z, Wellington GM, Fox GE, Toonen RJ (2015) Clues to unraveling the coral species problem: distinguishing species from geographic variation in Porites across the Pacific with molecular markers and microskeletal traits. PeerJ 3:e751 https://doi.org/10.7717/peerj.751

Friedlander AM, Ballesteros E, Beets J, Berkenpas E, Gaymer CF, Gorny M, Sala E (2013) Effects of isolation and fishing on the marine ecosystems of Easter Island and Salas y Gómez, Chile. Aquat Conserv 23:515-531

Glynn PW, Ault JS (2000) A biogeographic analysis and review of the far eastern Pacific coral reef region. Coral Reefs 19:1-23

* Glynn PW, Gassman NJ, Eakin CM, Cortes J, Smith DB, Guzman HM (1991) Reef coral reproduction in the eastern Pacific: Costa Rica, Panama, and Galapagos Islands (Ecuador) I. Pocilloporidae. Mar Biol 109:355-368

Glynn PW, Colley SB, Eakin CM, Smith DB and others (1994) Reef coral reproduction in the eastern Pacific: Costa Rica, Panamá, and Galápagos Islands (Ecuador). II. Poritidae. Mar Biol 118:191-208

Glynn PW, Wellington GM, Wieters EA, Navarrete SA (2003) Reef-building coral communities of Easter Island (Rapa Nui), Chile. Lat Am Coral Reefs 2003:473-494

* Glynn PW, Wellington GM, Riegl B, Olson DB, Borneman E, Wieters EA (2007) Diversity and biogeography of the scleractinian coral fauna of Easter Island (Rapa Nui). Pac Sci 61:67-90

Glynn PW, Colley SB, Maté JL, Baums IB and others (2012)
Reef coral reproduction in the equatorial eastern Pacific: Costa Rica, Panamá, and the Galápagos Islands (Ecuador). VII. Siderastreidae, Psammocora stellata and Psammocora profundacella. Mar Biol 159:1917-1932

Glynn PW, Colley SB, Carpizo-Ituarte E, Richmond RH (2017) Coral reproduction in the Eastern Pacific. In: Glynn P, Manzello D, Enochs I (eds) Coral reefs of the Eastern Tropical Pacific. Coral reefs of the world, Vol 8. Springer Science Business Media, Dordrecht, p 435-476

Guest JR, Baird AH, Goh BPL, Chou LM (2005a) Reproductive seasonality in an equatorial assemblage of scleractinian corals. Coral Reefs 24:112-116

Guest JR, Baird AH, Goh BPL, Chou LM (2005b) Seasonal reproduction in equatorial reef corals. Invertebr Reprod Dev 48:207-218

Guinotte JM, Buddemeier RW, Kleypas JA (2003) Future coral reef habitat marginality: temporal and spatial effects of climate change in the Pacific basin. Coral Reefs 22:551-558

Harriott VJ (1983) Reproductive ecology of four scleratinian species at Lizard Island, Great Barrier Reef. Coral Reefs $2: 9-18$

Harrison PL (2011) Sexual reproduction of scleractinian corals. In: Dubinsky Z, Stambler N (eds) Coral reefs: an ecosystem in transition. Springer Science Business Media, Dordrecht, p 58-85

Harrison PL, Wallace CC (1990) Reproduction, dispersal and recruitment of scleractinian corals. In: Dubinsky Z (ed) Coral reefs. Elsevier Science Publishers, Amsterdam, New York, NY p 132-207

Hubbard D, Garcia M (2003) The corals and coral reefs of Easter Island - a preliminary look. In: Loret J, Tanacredi JT (eds) Easter Island: scientific exploration into the world's environmental problems in microcosm. Springer, New York, NY, p 53-77

Jokiel PL, Ito RY, Liu PM (1985) Night irradiance and synchronization of lunar release of planula larvae in the reef coral Pocillopora damicornis. Mar Biol 88:167-174

Kerr AM, Baird AH, Hughes TP (2011) Correlated evolution of sex and reproductive mode in corals (Anthozoa: Scleractinia). Proc R Soc B 278:75-81

Kojis BL, Quinn NJ (1981) Aspects of sexual reproduction ad larval development in the shallow water hermatypic coral, Goniastrea australensis. Bull Mar Sci 31:558-573

Kough AS, Paris CB (2015) The influence of spawning periodicity on population connectivity. Coral Reefs 34: 753-757

Kroeker KJ, Micheli F, Gambi MC, Martz TR (2011) Divergent ecosystem responses within a benthic marine community to ocean acidification. Proc Natl Acad Sci USA 108:14515-14520

Kruger A, Schleyer MH (1998) Sexual reproduction in the coral Pocillopora verrucosa (Cnidaria: Scleractinia) in KwaZulu-Natal, South Africa. Mar Biol 132:703-710

* Laurindo LC, Mariano AJ, Lumpkin R (2017) An improved near-surface velocity climatology for the global ocean from drifter observations. Deep Sea Res I 124:73-92

Lessios HA, Baums IB (2017) Gene flow in coral reef organisms of the Tropical Eastern Pacific. In: Glynn P, Manzello D, Enochs I (eds) Coral reefs of the Eastern Tropical Pacific. Coral reefs of the world, Vol 8. Springer Science Business Media, Dordrecht, p 477-499

*Manzello DP, Kleypas JA, Budd DA, Eakin CM, Glynn PW, Langdon C (2008) Poorly cemented coral reefs of the eastern tropical Pacific: possible insights into reef devel- 
opment in a high- $\mathrm{CO}_{2}$ world. Proc Natl Acad Sci USA 105:10450-10455

Moore PJ, Thompson RC, Hawkins SJ (2011) Phenological changes in intertidal con-specific gastropods in response to climate warming. Glob Change Biol 17:709-719

Moraga J, Valle-Levinson A, Olivares J (1999) Hydrography and geostrophy around Easter Island. Deep Sea Res I 46: 715-731

Neves EG (2000) Histological analysis of reproductive trends of three Porites species from Kane'ohe Bay, Hawai'i. Pac Sci 54:195-200

*Paz-García DA, Chávez-Romo HE, Correa-Sandoval F, Reyes-Bonilla H, López-Pérez A, Medina-Rosas $P$, Hernández-Cortés MP (2012) Genetic connectivity patterns of corals Pocillopora damicornis and Porites panamensis (Anthozoa: Scleractinia) along the west coast of Mexico 1. Pac Sci 66:43-61

Paz-García DA, Galván-Tirado C, Alvarado JJ, Cortés J, García-De-León FJ, Hellberg ME, Balart EF (2016) Variation in the whole mitogenome of reef-building Porites corals. Conserv Genet Resour 8:123-127

* Permata WD, Kinzie RA III, Hidaka M (2000) Histological studies on the origin of planulae of the coral Pocillopora damicornis. Mar Ecol Prog Ser 200:191-200

Philippart CJM, van Aken HM, Beukema JJ, Bos OG, Cadée GC, Dekker R (2003) Climate-related changes in recruitment of the bivalve Macoma balthica. Limnol Oceanogr 48:2171-2185

Philippart CJM, Van Bleijswijk JDL, Kromkamp JC, Zuur AF, Herman PMJ (2014) Reproductive phenology of coastal marine bivalves in a seasonal environment. J Plankton Res 36:1512-1527

Poloczanska E, Hoegh-Guldberg O, Cheung W, Pörtner HO, Burrows MT (2013) Cross-chapter box on observed global responses of marine biogeography, abundance, and phenology to climate change. In: Field CB, Barros VR, Dokken DJ, Mach KJ and others (eds) Climate change 2014: impacts, adaptation, and vulnerability. Part A: global and sectoral aspects. Contribution of Working Group II to the Fifth Assessment Report of the Intergovernmental Panel on Climate Change. Cambridge University Press, Cambridge, p 123-127

R Core Team (2016) R: a language and environment for statistical computing. R Foundation for Statistical Computing, Vienna. www.r-project.org/

Richards RA (2012) Phenological shifts in hatch timing of northern shrimp Pandalus borealis. Mar Ecol Prog Ser 456:149-158

Richmond RH (1997) Reproduction and recruitment in corals: critical links in the persistence of reefs. In: Birkeland C (ed) Life and death of coral reefs. Chapman \& Hall, New York, NY, p 175-197

Editorial responsibility: Judith Grassle,

New Brunswick, New Jersey, USA
Richmond RH, Hunter CL (1990) Reproduction and recruitment of corals: comparisons among the Caribbean, the Tropical Pacific, and the Red Sea. Mar Ecol Prog Ser 60: 185-203

Riegl B, Glynn PW, Wieters EA, Purkis S, Angelo C, Wiedenmann J (2015) Water column productivity and temperature predict coral reef regeneration across the IndoPacific. Sci Rep 5:8273

Romero-Torres M, Acosta A, Treml EA (2017) The regional structure of spawning phenology and the potential consequences for connectivity of coral assemblages across the Eastern Tropical Pacific. ICES J Mar Sci 74:613-624

Schmidt-Roach S, Miller KJ, Woolsey E, Gerlach G, Baird AH (2012) Broadcast spawning by Pocillopora species on the Great Barrier Reef. PLOS ONE 7:e50847

Shlesinger Y, Loya Y (1985) Coral community reproductive patterns: Red Sea versus the Great Barrier Reef. Science 228:1333-1335

Sier CJS, Olive PJW (1994) Reproduction and reproductive variability in the coral Pocillopora verrucosa from the Republic of Maldives. Mar Biol 118:713-722

Stoddart CW, Stoddart JA, Blakeway DR (2012) Summer spawning of Porites lutea from north-western Australia. Coral Reefs 31:787-792

* Stoddart JA, Black R (1985) Cycles of gametogenesis and planulation in the coral Pocillopora damicornis. Mar Ecol Prog Ser 23:153-164

* Sydeman WJ, Bograd SJ (2009) Marine ecosystems, climate and phenology: introduction. Mar Ecol Prog Ser 393: 185-188

*van Woesik R (2010) Calm before the spawn: global coral spawning patterns are explained by regional wind fields. Proc R Soc B 277:715-722

Veron J, Stafford-Smith M, DeVantier L, Turak E (2015) Overview of distribution patterns of zooxanthellate Scleractinia. Front Mar Sci 1:81

Wellington GM, Glynn PW, Strong AE, Navarrete SA, Wieters E, Hubbard D (2001) Crisis on coral reefs linked to climate change. EOS Trans Am Geophys Union 82:1-5

*Wickham H (2010) A layered grammar of graphics. J Comput Graph Stat 19:3-28

*Wieters EA, Medrano A, Perez Matus A (2014) Functional community structure of shallow hard bottom communities at Easter Island (Rapa Nui). Lat Am J Aquat Res 42: 827-844

Wilson JR, Harrison PL (2003) Spawning patterns of scleractinian corals at the Solitary Islands - a high latitude coral community in eastern Australia. Mar Ecol Prog Ser 260: 115-123

*Wood S, Paris CB, Ridgwell A, Hendy EJ (2014) Modelling dispersal and connectivity of broadcast spawning corals at the global scale. Glob Ecol Biogeogr 23:1-11

Submitted: August 28, 2017; Accepted: December 19, 2017 Proofs received from author(s): February 6, 2018 